\title{
Evaluation of the Extent of Utilization of Electronic Library Resources and Services by Undergraduate Students in University of Calabar Library, Calabar -Nigeria
}

\author{
Bassey Ruth Simon,OduJames Ogom \\ University of Calabar Library, University of Calabar,Calabar, Nigeria
}

Email address:

ruthsimon_bassey@yahoo.co.uk (Bassey R. S.), ogomjodu@yahoo.com (Odu J. O.)

To cite this article:

Bassey Ruth Simon, Odu James Ogom. Evaluation of the Extent of Utilization of Electronic Library Resources and Services by Undergraduate Students in University of Calabar Library, Calabar - Nigeria. Education Journal. Vol. 4, No. 2, 2015, pp. 82-89. doi: $10.11648 /$ j.edu. 20150402.15

\begin{abstract}
An evaluation of the extent of utilization of electronic Library resources and services by undergraduate students in the University of Calabar, Nigeria, was carried out. The survey research design was used in this study whose population consisted of all registered undergraduate library users in the 2013/2014 academic session. Accidental sampling technique was used to select 300 respondents out of a total population of 4, 211 registered users. Questionnaire and direct observation were the instruments used for data collection. The data generated was analysed using descriptive statistics (simple percentage). The study revealed that the respondents became aware of the e-library mostly through library management efforts involving directional signs, freshmen orientation and library use education programme among others. The study further reported varying degrees of frequency and extent of utilization of, as well as increase duration of usage which could be attributed to some improvements in the development and provision of EIRS in services over the years. Benefit of the e-library facility as indicated by respondents ranged from academic to social networking, with attendant challenges of slow speed of internet access, inadequate numbers of computers, irregular power supply among others. The impact of e-library was revealed to include: global access to relevant resources, ease of communication, and increase in level of academic achievement among others.It was recommended in the study that there should be a holistic user education programme for library users, the number of computers in the e-library should be increased, e-library staff should be trained with the requisite technical skills to manage the resources effectively and the directorate of ICT should ensure improve internet access and networking within the University Community.
\end{abstract}

Keywords: Electronic Information Resources, Electronic Library, Evaluation, University Library, Undergraduate, Nigeria

\section{Introduction}

The development of effective information delivery system is a key component of university teaching and learning, and modern technology greatly enhances the process. It was towards this end, that the $3^{\text {rd }}$ declaration of AAU on the African universities in the $3^{\text {rd }}$ Millennium enjoined universities to give priority to effective and positive participation in global creation, exchange and application of knowledge. It further urged universities to exploit fully the potentials of the ICT revolution to enhance teaching, learning, research and management; stressing that urgent consideration be given to recent developments in teaching, applications, networking and opportunities for lifelong learning. Within the context of universities and other academic institutions, libraries have been at the forefront of providing information resources and services to their respective communities of students, teachers and researchers to support academic and scholarly work. Yusuf and Iwa (2010) explain that library should be the nerve or hub around which scholarships revolve. Sources of information available within academic libraries according to them should promote active learning and contribute towards student and scholars' ability to think critically and expand overall societal progress.

Over the years, the supply of various needs and demands by University libraries was achieved through an essentially manual process of acquisition, organization, preservation and dissemination of printed materials comprising of books, journals, periodicals etc as well as considerable number of audiovisual resources. Accordingly, a high quality academic 
library was defined by the quantity of its holdings and not the quality of its access to information which presently separates excellent libraries from mediocre ones (Heyneman, 2010). The traditional role of building large collections of information resources to meet patrons demands and attendant constraints of time and space, low productivity and high cost of staffing, resources and services among others, have significant implications for the current era, typified by increasing importance and availability of information; with ICT as the driving force and defining parameter for information search, retrieval and basic infrastructure for research, teaching and learning.

Developments in ICTs, according to Jacobs (2013) are presenting rapid growth in the availability of inter alia electronic/digital information, subject depositories and digital contents. With the evolvingdigital library services, online access to information, automation of library operations, establishment of library networking and resource sharing, the adoption of ICTs has no doubt changed the traditional face of academic libraries and contributed to the improvement in the provision of quick and quality services to learners and scholars. Libraries in developed countries are thus leveraging with the benchmark of full electronic library operations, providing quicker and multiple access to limitless streams of information resources, simply referred to as electronic resources or popularly known as e-resources. Electronic resources are resources in which information is stored electronically according to Harison and Khan(2009). They include electronic books, electronic journals, online/electronic databases, electronic conference papers/proceedings, electronic newspapers/magazines and electronic technical reports.

The rapid diffusion, adoption and integration of ICTs in acquisition, processing, storage and retrieval, and dissemination of information in Nigerian university libraries within the past two decades has enhanced the provision of electronic information resources/services to library users through the development of electronic libraries. As a catalyst to the digital revolution in Nigeria, the Federal Government of Nigeria through the Federal Ministry of Education approved the establishment of the Nigerian Virtual Libraryin 2002. Although, the Nigerian Virtual Library project (NVPL) was not implemented as proposed; it has given birth to the development of electronic/digital libraries by individual universities and other academic institutions in Nigeria. Presently, the virtual library is run by the National Universities Commission (NUC), it has a lot of electronic resources to support learning, teaching and research in Nigerian universities. Access to the virtual library is institutional based, with pass words given to each public university in Nigeria, with which students and staff of the University of Calabar can access the virtual library from the e-library, University of Calabar.Many Nigerian Universities Libraries have also adopted ICTs in their provision of facilities, collections and service delivery. They are incorporating electronic resources to expand their collections and frontier of services. As traditional paper based collections and manual procedures and services would continue to be relevant in teaching, learning and research in academic institutions especially in developing countries like Nigeria, with poor ICT infrastructural facilities, the term hybrid library is being used to describe the present scenario where print resources are juxtaposed with electronic collections, internet and online facilities and services.

The employment of ICTs to drive communication, collaboration and shared access to knowledge across national and international boundaries is thus impacting greatly on the learning environment in Nigerian Universities, especially with the recent commissioning of the Nigerian Research and Education Network (NgRen) on the $8^{\text {th }}$ of July 2014, bringing Nigeria to the verge of making a giant leap in $21^{\text {st }}$ century teaching and research. In 2011, the Federal Ministry of Education established the NUC database wifi project in the university of Calabar, at the same time Electronic library services were being developed to supply supplementary resources to the conventional library. The electronic library, University of Calabar which was donated by Deep Offshore Community affairs Group (DOCAG), Nigeria, a conglomerate of oil companies/oil serving companies in Nigeria (TOTAL, NNPC, Shell, Chevron etc), was commissioned on the $19^{\text {th }}$ December 2012 by Mr. M.A. Fiddi, group General Manager, NNPC-NAPIMS. It provides access to a number of electronic resources such as electronic databases, CD-Rom databases (TEEAL), open access journals and e-books. It has a capacity of 268 desktop computers and runs on both wired and wireless networks. The University of Calabar postgraduate digital library was commissioned in September 2014 by the Chairman of Council, University of Calabar, Dr. Emmanuel Iwuanyawu. The goal of the digital library is to provide access to quality information to postgraduate students and staff of the university. From the foregoing, it could be assumed that University of Calabar students, faculty members, administrators and researchers are offered enormous opportunities to access the most current books, journals as well as abstracts or indexes from popular online databases and world class publishers across the globe.

However, it is obvious that effective utilization of e-library and e-resources depends absolutely on the following variables: availability of computers and internet access, network connectivity, highly skilled personnel and steady power supply. Each of these variables can, if properly harnessed, influence the performance of the e-library and guarantee sustenance of the gains of leveraging with the electronic information environment benchmark. This would call for periodic evaluation with a view to identifying the strengths and the weaknesses of the electronic library system. Such evaluation could reveal users' perception of the services rendered by the e-library, the performance rate of the ICT infrastructure, the extent of utilization of the e-resources and services and the level of ICT literacy among the different categories of users.

The question therefore arises as to whether the University of Calabar Library has overcome significantly the challenges associated with poor access to current and up-to-date 
information resources? Additionally, whether the e-library is optimally utilized and if the users have reasonable ICT literacy level to enable them key effectively into the services offered. More importantly, the level of efficiency of the various ICT infrastructures in the e-library has not been evaluated since installation. One is therefore not certain whether the e- library's strategic and operational objectives are being met.

\section{Statement of the Problem}

The value of a library, electronic or traditional, could be determined by the extent of accessibility and utilization of its resources. This can be measured by use statistics derived from such library. A rich library, with large volumes of information resources, both physical and electronic, that cannot be accessed or effectively utilized is meaningless. The concept of electronic library evolved out of the need to overcome the challenges associated with the physical library and usher the information seekers, irrespective of their location and time, into the global world of electronic information resources.

In view of the enormous resources involved in the development and maintenance of e-library, it is necessary to monitor its operation to ensure that the strategic and operational objectives are met. Such periodic evaluation can help determine the extent of accessibility and utilization of the e-library resources and services of the e-library in the University of Calabar, as well as the level of awareness of the existence of such priceless research infrastructure. The various ICT infrastructures installed and the value of the ICT personnel in relation to the objectives of the electronic library, have not been assessed since the commissioning of the facility.

It is against this background that this study was embarked upon, to evaluate the electronic library in the University of Calabar with a view to ascertaining the level of awareness of the e-library resources and services, the functionality of the various ICT facilities, the extent of accessibility and utilization of the e-library, users' perception of the of the elibrary and how the e-library is managed vis a vis the objectives of the library.

\section{Objectives of the Study}

The main objective of this study was to evaluate the performance of the electronic library in the University of Calabar in line with the purpose of establishing the e-library. The specific objectives were as follows:

1. To ascertain how users became aware of the e-library in the University of Calabar.

2. To determine the extent of utilization of e-library resources and services in the University of Calabar.

3. To identify the challenges associated with the utilization of electronic library in the University of Calabar.

4. To identify the reasons why clients use the electronic library resources and services, and
5. To assess the impact of e-library resources and services on the users.

\section{Review of Related Literature}

Evaluation of library services is an essential tool or feedback mechanism for understanding users' perception and opinion concerning library services in general. According to Nadiri and Mayboudi (2010), library services evaluation helps librarians to understand users' perception and it contributes towards providing information to aid future development in improving library services quality and meeting users needs better. According to Ukachi and Okeke (2012), it is necessary to evaluate the utilization of services provided by electronic libraries vis a vis the objectives for establishing them. This they believed, would expose the existing lapses and give room for amendments and correction where necessary.

The rational for the transition from the physical or manual library operation to the electronic library system have variously been acknowledged. Edem and Afebende (2011), noted that electronic library makes available to a single user lots of current information from various resources including networked resources of other libraries. Other studies that justified the need to embrace electronic resources and services in Nigeria university libraries included Okebukola (2002), Afolabi, (2007), Faborde, (2007) and Bozimo, (2007).

The poor availability and obsolescence of books, journals and other learning materials have always posed a problem that impairs the ability of higher educational institutions in Africa to adequately achieve their purpose of teaching, research and community services for their expanding population of students, (UNESCO, 2003). In their study on the extent to which information seeking behaviour of researchers in the universities in UK and the wider world has changed as a result of the development of electronic information revolution, Ellis and Oldman, (2005), found that different types of electronic information resources (EIRs) were now available to researchers. This however has reduced the time spent to gain access to research information.

Similarly, Fatoki, (2004), investigated the impact of electronic information resources, particularly the internet on undergraduate students research result in university of Ibadan, Nigeria. The finding showed that only a few university libraries in Nigeria are able to provide access to these resources for their staff and students due to the apparent poor development of electronic information resources (EIRs). The study recommended that Nigerian University libraries should work cooperatively to facilitate access to EIRs. Ani, (2005), in a study investigated the prospect and possibility of developing electronic (Virtual) libraries in Nigerian University libraries. The investigation concluded that Nigeria has relevant ICT infrastructure for successful evolution of Virtual Libraries in the country.

In a study on the problems encountered by Librarians in the utilization of Information and Communication Technology (ICTs) in Nigerian University Libraries, Igun, 
(2003) noted that, there is a general level of awareness and obvious utilization of ICTs in Nigerian University Libraries, though there are still major challenges being encountered: lack of adequate funding, lack of expertise, frequent electricity interruption, lack of maintenance and sustenance of ICT infrastructure, etc. Jagboro (2003), in a study on ICT utilization at the ObafemiAwolowo University, Ile Ife, found that $22.1 \%$ of the respondents accessed the Internet on a daily basis, $38.2 \%$ on a weekly basis, $11.8 \%$ on monthly basis and $16.2 \%$ quarterly. The study further revealed that $25 \%$ of the respondents spent an average time of half an hour on the Internet per week, $39.7 \%$ spent one hour, $19.1 \%$ spent two hours, 7.4\% spent three hours and 3.0\% spent four hours while $5.9 \%$ spent more than four hours.

According to Okunlaya, Emmanuel and Ajegbomogun, (2014), the major purpose of using ICT by students in Nigerian University Libraries was for academic work and email services and to compliment what the lecturer taught in class. This can improve the knowledge acquired and encourage the exploitation of information resources for technical development. Wombo and Abba (2004), quoted in Tion and Echezona (2014) observed that the implementation of ICT in Nigerian University Libraries was intended to provide e-library resources and services to users. According to them, this requires so much money for acquisition, installation, maintenance, training and sustainability of the project. Money is needed to maintain and upgrade equipment, pay software licence fees, etc.

It is however clear from the above literature review that library investment has tremendous impact on scholarship and academic work of students and staff in tertiary institutions. Libraries should constantly articulate their concrete contributions to the overall mission and objectives of the parent institutions to justify or warrant continued investment. Evaluating e-library services is therefore important in providing evidence of the benefits and impacts of EIRs, gaining the support of stakeholders as well as contributing to securing funding for further development.

\section{Research Methodology}

This study was conducted in the University of CalabarLibrary, Calabar, Nigeria. Survey research design was used for the study. The population of the study consisted of all registered library users in the 2013/2014 academic session. The total population of the study was 4, 211 registered users. Accidental sampling technique was use to select 300 respondents who constituted the sample of the study. Questionnaire and direct observation were the instruments used for data collection. The questionnaire was accidentally administered to library users in the e-library. The questionnaire were administered and collected on the spot. This was repeated for four days and 300 questionnaires were administered within the period. The data generated were analysed using descriptive statistics (simple percentage \%).

\section{Presentation of Results}

The data on the level of awareness of the availability of electronic library resources and services in the University of Calabar is presented as follows:

Table 1. The level of awareness of the availability of e-library resources and services in the University of Calabar, Nigeria.

\begin{tabular}{lll}
\hline Available options & $\begin{array}{l}\text { Number of } \\
\text { respondents. }\end{array}$ & Percentage \% \\
\hline $\begin{array}{l}\text { During orientation programme. } \\
\text { Through a library staff }\end{array}$ & 77 & 25.6 \\
$\begin{array}{l}\text { Through a friend/ fellow } \\
\text { students }\end{array}$ & 11 & 3.7 \\
$\begin{array}{l}\text { Through directional signs } \\
\text { Through the University website }\end{array}$ & 94 & 21.3 \\
$\begin{array}{l}\text { Through user education } \\
\text { programme. }\end{array}$ & 41 & 32.0 \\
Total & 300 & 3.7 \\
\hline
\end{tabular}

The data on table 1 above show the various means through which the respondents became aware of the availability of elibrary resources and services in the University of Calabar. 96 respondents (32\%) knew about the e-library through directional signs in the library, 77 respondents $(25.6 \%)$ during orientation programme, 64 respondents $(21.3 \%)$ through friends or fellow students, 41 respondents (13.7\%) through user education programme, while 11 respondents $(3.7 \%)$ knew about it through library staff and the university website.

The data on the extent of utilization of library resources and services are presented as follows:

Table 2. The extent of utilization of e-library resources and services in the University of Calabar Library.

\begin{tabular}{llllll}
\hline Frequency of use & Respondents & \% & Average timespent & Respondents \\
\hline Daily & 69 & 23.0 & One hour daily & 81 & \% \\
Twice a week & 87 & 29.0 & $2-3$ hours daily & 99 & 74 \\
Monthly & 52 & 17.3 & $4-5$ hours daily & 33 \\
Quarterly & 75 & 25.0 & Above 5 hours daily & 46 & \\
Occasionally & 17 & 5.7 & & 300 \\
Total & 300 & 100 & Total & 15.3 \\
\hline
\end{tabular}

As shown in table 2 above, $23 \%$ of the respondents used the e-library daily, $29 \%$ used it twice a week, $17.3 \%$ used the e-library monthly, $25.0 \%$ used it quarterly and $5.7 \%$ used the e-library occasionally. Similarly, $27.0 \%$ of the respondents spent an average time of 1 hour in the e-library daily, $33.0 \%$ spent 2-3 hours daily, $24.7 \%$ spent $4-5$ hours daily and $15.3 \%$ spent over 5 hours daily in the e-library.

The data on the rational for using the e-library were 
presented as follows:

Table 3. Showing the rational for using the e-library.

\begin{tabular}{|c|c|c|c|c|c|}
\hline Available options on reasons for usage & Respondents & $\%$ & Preferred e-resources & Respondents & $\%$ \\
\hline Academic and research work & 151 & 50.3 & Search engines & 73 & 24. \\
\hline Social networking & 48 & 16 & e-books & 66 & 22 \\
\hline Business & 5 & 1.7 & e-Journals & 31 & 10.3 \\
\hline Entertainment & 23 & 7.7 & OPAC & 53 & 17.7 \\
\hline Current awareness & 53 & 17.7 & Online databases & 12 & 4.0 \\
\hline \multirow[t]{2}{*}{ Scholarship infor. } & 20 & 6.6 & e-theses/Dissertations & 22 & 7.4 \\
\hline & & & e-Newspapers/Magazines & 43 & 14.3 \\
\hline Total & 300 & 100 & Total & 300 & 100 \\
\hline
\end{tabular}

Different reasons were given by the respondents for using the e-library resources and services as shown in table 3 above. $50.3 \%$ of the respondents used the e-library for academic work and research, $16.0 \%$ used the e-library for social networking, $1.7 \%$ used it for business transaction, $7.7 \%$ used it for entertainment, $17.7 \%$ used it for current awareness and $6.6 \%$ used it for sourcing scholarship information. Similarly, $24.3 \%$ of the respondents relied on search engines, $22 \%$, used e-books, $10.3 \%$ used e-journals, $17.7 \%$ used the online public access catalogue (OPAC), 4.0\% used online databases, 7.4\% used e-Theses/Dissertations and $14.3 \%$ used e-News papers/Magazines.

The data on the preference between the physical and elibrary was presented as follows:

Table 4. Showing the respondents' preference between the physical library and the electronic library.

\begin{tabular}{lll}
\hline Options & Respondents & \% \\
\hline Yes & 244 & 81.3 \\
No & 56 & 18.7 \\
Total & 300 & 100 \\
\hline
\end{tabular}

The finding on which is more preferred, between the physical library and the electronic library presented in table 4 showed that $81.3 \%$ of the respondents preferred the electronic library over the physical library, while $18.7 \%$ preferred the physical library over the electronic library.

The data on the challenges encountered in using the electronic library was presented as follows:

Table 5. Showing the various challenges encountered in using the electronic library.

\begin{tabular}{lll}
\hline Available options & Respondents & $\%$ \\
\hline Irregular power supply & 40 & 13.3 \\
Poor attitude of library staff & 31 & 10.3 \\
Limited access to available resources & 23 & 7.7 \\
Slow speed of internet access & 74 & 24.7 \\
Lack of user education & 40 & 13.3 \\
Inadequate number of computers & 92 & 30.7 \\
Total & 300 & 100 \\
\hline
\end{tabular}

The finding reveals certain factors that inhibit effective utilization of the e-library as presented in table 5 above. Irregular power supply $13.3 \%$, poor attitude of library staff $10.3 \%$, limited access to available resources $7.7 \%$, slow speed of internet access $24.7 \%$, lack of user education $13.3 \%$ and inadequate number of computers $30.7 \%$.
The data on the impact of availability and utilization of elibrary resources is presented as follows:

Table 6. Showing the impact of availability and utilization of e-library resources.

\begin{tabular}{lll}
\hline Available options & Respondents & \% \\
\hline Improved quality of academic work & 40 & 13.3 \\
Increase in level of academic achievement & 65 & 21.7 \\
Global access to relevant resources & 74 & 24.7 \\
Ease of communication & 62 & 20.7 \\
Efficiency in access and use of e-resources. & 59 & 19.6 \\
Total & 300 & 100 \\
\hline
\end{tabular}

The finding also revealed the impact of ICT utilization on the users as shown on table 6 . Improved quality of academic work $13.3 \%$, increase in the level of academic achievement $21.7 \%$, global access to relevant resources $24.7 \%$, ease of communication $20.7 \%$, efficiency in accessibility and utilization of e-resources $19.6 \%$

\section{Discussion}

The level of awareness of the e-library facility is quite high as showed by $100 \%$ respondents, indicating various means of getting to know about the system. It is significant that out of this, library management efforts at marketing the service and ensuring patronage by the University community through directional signs, orientation and user education taken together accounted for 214 or $71.3 \%$ rating. Surprising however, is the relatively low rating of 11 or $3.7 \%$ for the university website which should be a major visibility variable for the University and its constituents, including the provision of access point to e-resources and services for the University Community.

Ajuwon et al (2003) had earlier surveyed the uptake of ICTs by health science students at the university college hospital, Ibadan and reported that $57 \%$ of students sampled could not use a computer, that the use of databases was poor due to lack of awareness among other factors. Their findings were later upheld by Okike (2012) who recorded a 55\% awareness and by implication corresponding average level of usage of subscribed electronic information resources by academic staff members of university of Lagos. Although university investment on e-resources has tremendous impact 
on teaching, research and scholarship, effective utilization of available resources will however depend to a large extent on marketing, training and liaison between the library management and user community. In summing up this imperative, Fatoki (2005) stressed that providing current awareness services to an ICT driven target academic community requires dynamic, innovative and adequate communication technologies.

Given the above, one may have expected that the frequency of use and extent of utilization of e-resources and services in present study will level up with the level of awareness reported. Rather, regular frequency of daily use and twice weekly accounted for 156 or $52 \%$ while 99 or $33 \%$ use the e-library for 2-3 hours daily. Studies by Jagboro (2003); Egberongbe (2011) had reported similar varying degrees of frequency and extent of utilization of e-library facilities at ObafemiAwolowo University, Ile Ife and University of Lagos respectively. Jagboro's survey in particular showed lower percentages for increased duration of usage, for example $8.9 \%$ for $4-5$ hours as against $24.7 \%$ shown by present study. The likelihood that the development and provision of EIRS and services may be witnessing some improvement over the years can plausibly account for observed increased duration of usage. Related studies (Womboh and Abba, 2008; Etim, 2006; Ani, et al, 2005) had reported series of efforts made by academic libraries in Nigeria to adopt technologies for improved information access, citing such constraints like erratic internet access, unstable power supply, inadequate infrastructure, human resource deficit and low level technological and literacy skills among others. In the same vein, researchers are discussing how these various challenges are being tackled so that Nigerian university libraries can benefit from e-library initiatives, especially resource sharing due to the variety of electronic/digital formats and platforms available. For Daniel (2014), achieving this will involve energetic, technical and content development as well as equipping libraries with right staff, with right skills and working within right structures. Jacobs (2014) also adds that Nigerian university libraries must identify and exploit alternative funding and collaborative opportunities to ensure that they are able to promote research and education within their institutions towards socio-economic development.

Similar to previously cited studies and many others, the benefits of e-resources utilization are enormous ranging from academic to social networking; and keeping abreast with developments in any field under consideration. The added advantage of having quicker and multiple access to required information from variety of electronic/digital formats - ebooks, e-journals, e-newspapers/magazines, as well as available platforms like search engines, online databases, OPAC, etc is also amply demonstrated. However, the preference for use of search engines $(24 \%)$ more than online databases $(4 \%)$ which are specifically subscribed to by library management to support research and scholarship should be noted as having implications for level of information literacy skills of student users and training on access to and use of online databases. Suffice to state that studies by Ani et al, (2014) and Sivathassan (2013) have reported both faculty and students' use of e-resources to access information available worldwide for teaching, learning and research. Ani et al took the research process a step further by drawing a corollary between EIRs accessibility and utilization on productivity of academic staff in surveyed universities, and reported a positive correlation, explaining that increase in access and use of e-resources will lead to increased productivity of academic staff. Interestingly though $81.35 \%$ of the respondents in present study indicated preference for the electronic library to the main university library despite the numerous challenges affecting usage, the most significant ones being inadequate number of computers, slow speed of internet access, unsteady power supply and lack of training on use of resources. To date, these problems have militated against adequate provision of e-resources and services in Nigerian university libraries. However, efforts aimed at considerably reducing the difficulties challenging the process and minimizing their impact are being discussed by relevant stake-holders, the most recent being efforts at developing standards and guidelines for e-library in Nigeria by National Information Technology Development Agency (NITDA) in collaboration with Librarians' Registration Council of Nigeria (LRCN). Hence, University of Calabar like many others has been developing EIRs through computerization, internet connectivity, subscription to electronic databases, digitization and resource sharing while maintaining traditional paper based collections and manual services and practices alongside. The preference for EIRs observed earlier is generally understood with respect to unrestricted access to unlimited information resources, access to more current information and provision of extensive links to additional resources related content (Dadzie, 2007). That notwithstanding, majority of lecturers $(53.6 \%)$ and research scholars $(53.3 \%)$ in Egbenongbe's survey stated that eresources will never diminish the importance of traditional resources as against $37.5 \%$ lecturers and $47 \%$ scholars who indicated otherwise. The indication that academics are still very much using traditional library resources despite the proliferationof IT should not be seen to contradict the findings of present study where millennials or digital natives, raised in a wired generation (1981-present) are concerned. A closer look at the millennial information seeking behaviour shows impatience for speed and down load of information, mainly digital access to information as well as demand for immediate response and instant gratification (Jacobs, 2013). Their positive response to well developed electronic library systems which can interface, articulate and intelligently respond to these demands should thus not be surprising.

\section{Conclusion and Recommendations}

The role of ICT and its facilities as a basic research infrastructure cannot be over emphasised. The concept of electronic library revolves around the application of ICT facilities in acquisition, preservation, dissemination, search 
and retrieval of information. With ICT, it has become relatively easier and faster to access dozens of data bases in different parts of the world. University libraries therefore, integrate e-library resources and services to compliment the obvious challenges associated with physical library. There is therefore the need to ensure fast internet connectivity and relatively adequate ICT facilities to guarantee optimal utilization of e-library resources and services.

It is a known fact that there is no one library that is self sufficient. It becomes imperative to evolve collaborative efforts among libraries to facilitate resource sharing. Thus, adoption and utilization of ICT facilities becomes a basic panacea in facilitating resource sharing. This is more apt in the developing countries where the challenges associated with information search, retrieval and communication are high. The use of ICT will obviously strengthen and equip all the libraries for adequate cooperation and resource sharing. It is hereby recommended as follows:

1. There should be a holistic user education programme designed to equip library users with the prerequisite skills on computer application, internet access, networking, database searches and information retrieval. The essence is to ensure that all categories of library users can participate in optimal utilization and should be able to carry out more detailed searches beyond the web pages to support and enhance academic work.

2. There is need to increase the number of computers in the e-library to accommodate more users at the same time. This would avoid the crowd created outside the elibrary by potential users waiting for the opportunity to use the library.

3. The directorate of ICT should improve internet access and networking with departments and faculties to ensure that e-resources available can be accessed by the University community from any location and at any time.

4. The e-library staff should be trained with the requisite technical or IT skills to manage resources effectively and assist users in their quest for information needed to meet their diverse needs.

\section{References}

[1] Ajuwon, G.A. (2003). Computer and Internet Use by First Year Clinical and Nursing Students in a Nigerian Teaching Hospital. BMC Medical Informatics and Decision Making, 3 (10)

[2] Ani, O. E. (2005). Evolution of Virtual Libraries in Nigeria: Myth or reality. Journal of InformationScience. 31 (1) 67-70.

[3] Bozimo, D. O. (2006). Information and Communication Technology (ICT) and Ahmadu Bello University Library. Nigerian Libraries: Journal of the Nigerian LibraryAssociation. 39, 1-17.

[4] Dadzie, P. S (2005). Electronic Resources; Access and Usage at Ashesi University College. Campus-Wide Information System 22(5) 290-297.
[5] Daniel, J. O (2014) Issues in Setting up E-Library in Nigeria. Paper Presented at the Tetfund E-Library Training Workshop For Colleges Of Education In Nigeria, October $20^{\text {th }}-31^{\text {st }}$.

[6] Edem, M. B. \&Afebende, G. (2011). Developing Digital Libraries for improved academic information provision in Nigeria. Library and Information Science Practitioner. 4 (1 \& 2) 313-323.

[7] Egbenongbe, H. S (2011). The Use and Impact of Electronic Resources at the University Of Lagos. Library Philosophy and Practice

[8] Ellis, D. \&Oldman, H. (2005). The English Literature Researcher in the age of the Internet. Journal of Information Science. 31 (1) 29-36.

[9] Etim, F. E (2006) Resource Sharing in the Digital Age: Prospects and Problems in African Universities. Available at Http:11digital Commons. Unl.Edu. Lipphrlprc/98.

[10] Fatoki, C. O. (2004). The impact of Library resources and Internet on undergraduate students' research: University of Ibadan, Nigeria. Nigerian Libraries: Journal of the Nigerian Library Association. 38 (!) 27-33

[11] Heyneman, S. P. (2006) Global Issues in Higher Education. Ejournal USA II (1), 52.

[12] Igun, S. (2013). Problems encountered by Libraries in the utilization of Information and Communication technology (ICT) in Nigerian University Libraries. Nigerian Libraries: Journal of the Nigerian Library Association. 46 (2) 87-99.

[13] Jacobs, L (2013) ICT Library Services in Nigerian Academic Institutions. Paper Presented At Workshop On ICT Library Services In Nigerian Tertiary Institutions By Regenesys Business School, Johannesburg $27^{\text {th }}$ Septembers.

[14] Jagboro, K. O. (2003). A study of Internet usage in Nigeria: A case study of ObafemiAwolowo University, Ille-Ife, Nigeria.Retrieved on September 15, 2011 from http://www. Firstmoday.organizations/issues8.2/jagboro/index.html.

[15] Nadiri, H. \& Mayboudi, S. M. A. (2010). Diagnosing university students' zone of tolerance from university library services. Malaysian Journal of Library and Information Science. 15 (1) 1-21.

[16] National Universities Commission,(2001). National virtual library project. Abuja: NUC.

[17] NITDA/LRCN 2013. Standards and Guidelines for E-Library in Nigeria

[18] Ogbebor, O. (2008). A review of trends and issues affecting academic libraries in higher education. nla-online forum. Available at http://ukmgt41.mail.yahoo.com/neo/launch?reason $=1 . \quad$ Tuesday 5 February, 2013.

[19] Okebukola, p. (2002). Key issues in developing the national virtual library. Education Today 9 (1) 3-8.

[20] Okiki, O. C. (2012) Electronic Information Resources Awareness, Attitude and Use by Academic Staff Members of University of Lagos, Nigeria. Library Philosophy and Practice (E-Journal) Available At Http://Digital Commons. Unl.Edu/Libphilprac/834. 
[21] Okon, E. A; Ngulube,P And Onyoncha, B (2014) Effects Of Accessibility And Utilizations Of Electronic Information Resources On Productivity Of Academic Staff In Selected Nigeria Universities In Science Research 2 (6): 166-171

[22] Okunlaya, R. E. A., Emmanuel, S. O. \&Ajegbumogun, F. O. (2014). An analysis of Internet resources utilization among students in humanities in some selected universities in Nigeria. Nigerian Libraries; Journal of the Nigerian Library Association. 47 (1) 51-66.

[23] Ross, L. \&Sennyey, P. (2008). The Library is dead, long live the Library: The practice of academic librarianship the Digital Revolution. The Journal of Academic Librarianship. 34 (2) 145-152

[24] Sivathaasan, N (2013) Use of Electronic Resources and Academic Performance of University Teachers: A Case Study. European Journal of Business and Management 5 (14) 46
[25] Tion, S. D. \& Echezona, R. I. (2014). Problems involving university libraries in the promotion of electronic learning in selected Federal University Libraries in the North Central Nigeria. Nigerian Libraries; Journal of Nigerian Library Association. 47 (1) 67-77.

[26] Ukachi, N. B. \& Okeke, J. R. (2012). Utilization f MTN Foundation Digital Library Project in Nigerian University Libraries: a case study f University of Lagos. Abuja Infolib: Journal of Library and Information Science. $6(1$ \& 2) 83-93

[27] UNESCO (2003). Feasibility study on the development of a virtual library by institution of higher education in Nigeria. Abuja: Consultancy Support Services LTD. 